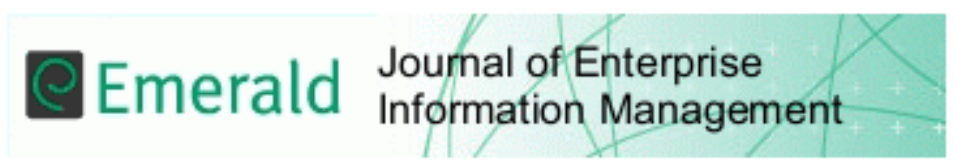

\title{
Understanding Barriers of Circular Economy: Cases from the Manufacturing Industry
}

\begin{tabular}{|r|l|}
\hline Journal: & Journal of Enterprise Information Management \\
\hline Manuscript ID & JEIM-02-2019-0047.R2 \\
\hline Manuscript Type: & Research Article \\
\hline Keywords: & Circular Economy, Barriers of Circular Economy, Manufacturing Industry \\
\hline \multicolumn{2}{|r}{} \\
\end{tabular}

\section{SCHOLARONE \\ Manuscripts}




\section{Understanding Barriers of Circular Economy: Cases from the Manufacturing Industry}

\section{Abstract \\ Purpose}

Most companies include a commitment for sustainable growth involving a switch towards the circular economy_(CE) model. This implies a radical change in the way businesses operate to obtain growth, but this is challenging since circular operations involve more complex flows than linear operations. Companies are faced with a range of technological and cultural barriers to overcome, and for the manufacturing sector, it is imperative to understand what barriers they face in order to take appropriate action. The purpose of this paper is to present barriers to eireular economy (CE) adoption identified by a literature review ${ }_{-}$. The paper alsoand to addresses the particular challenges faced by manufacturers by answering the research question: What are the dominant barriers faced by the manufacturing industry in moving towards a CE?

\section{Design/methodology/approach}

This paper presents a literature review of research identifying barriers for adopting to CE in the manufacturing sector. - The literature review is followed by a case study identifying barriers to $\mathrm{CE}$ as seen by 10 companies within manufacturing including the GS1 global information standardisation agency used by all manufacturers. The case study collects data by semi-structured interviews focusing on how companies understand the circular economy $\underline{\mathrm{CE}}$, and what barriers they face towards circular economy $\underline{\mathrm{CE}}$ implementation.

\section{Findings}

The manufacturers investigated focus mostly on recycling and waste reduction. These policies have low, or very low CE-effect. High CE-effect policies like maintenance and reuse targeting the $\mathrm{CE}$ ideal of no-waste, are nearly non-existent. The results identified seven main barriers to the circular economy: 1) High start-up costs, 2) Complex supply chains, 3) Challenging Business to Business (B2B) cooperation, 4) Lack of information on pProduct design and production, 5) Lack of technical skills, 6) Quality compromise and 7) Disassembly of products is time-consuming and expensive.

\section{Research limitations/implications}

The data comes from participants in a single country, Norway, although the manufacturers are multinational companies adhering to enterprise policies.--

For each company, one or two persons were interviewed giving their personal view, other persons might have a different view.

\section{Practical implications}

This research shows that all the companies interviewed are well aware of the growing need for their company to move towards more sustainable operations involving eireular economy $\mathrm{CE}$ concepts. The barriers identified are explored and findings could guide such companies in their efforts to move to maintenance, reuse, remanufacture and recycle $(\mathrm{M}+3 \mathrm{R})$ operational model.

\section{Social implications}


The study has found that the major barriers for implementation of CE are a quality issue in recycled materials, supply chain complexities, coordination problems between companies, design and production of the product, disassembly of products and high start-up/ investment costs.

\section{Originality/value}

The research shows how the transition towards a eireular economy $\underline{C E}$ takes place in manufacturing industries by studying the manufacturing sector.

\section{Introduction}

Whilst globalisation gives both a larger market and increased competition, the companies' supply chains have become more complex and critical than before (Majta 2012, Sheffi 2018). The rate of worldwide consumption has increased eight times over several decades, and it is expected that the resource use globally will increase three times more until 2050 (Lucas 2014). The effect of population growth and the subsequent increase in consumption challenges the environment, overall society, and the depletion of scarce resources (Damen 2012, Ellen MacArthur Foundation 2014). The resource consumption of the linear model follows the take-make-consume-dispose pattern. This is not sustainable as the over-use of scarce resources contribute to pollution of the environment. Cities are generating 1.3 billion tons of waste each year, with significant overuse of trash landfills. This figure will surge to 2.2 billion tonnes by 2025 (Masi et al., 2017). Electronic waste is another kind of waste that is increasing quickly. We know that waste and trash have a negative impact, with our oceans accumulating plastics, endangering marine life, animals and wildlife affected by too many pollutants, persistent use of chemicals causing disease, depletion of the ozone layer, and global warming all leading to a focus on taking serious action against waste.

Businesses and their supply chains in their need to satisfy their customers must increase the price of the materials due to the increasing scarcity of resources, which again affects progress and profitability of the companies in a negative way. In considering demand, more pressure of environmental concern from customers is seen to result in more ecofriendly products. The CE model is based on the concept of changing the take-make-usedispose pattern into closed-loops of material flows. Closed loops of materials are possible through different functions i.e. maintenance, repair, reusing, refurbishing, remanufacturing and recycling. This creates the synergy effect between economic development and the environment (Masi et al., 2017). Supply chains are considered to be an important factor for the implementation of the eircular economyCE model because of the need for a joint effort by suppliers and manufacturers. The co-operation and co-ordination between supply chains 'upstream' and 'downstream' partners are essential as upstream partners obtain eco-friendly inputs cooperating with downstream partners for environmental management practices such as product return, reuse and recycling (Zhu et al., 2010). The transition to CE is not easy, as is evident from previous studies. Due to these barriers, firms are slow to make a transition towards the circular economy $\underline{\mathrm{CE}}$ (Masi et al., 2017; Preston, 2012). This research targets the barriers to the eireular economy $\mathrm{CE}$ in manufacturing industries and the ways these barriers can be overcome.

The paper first defines manufacturing industries and considerations leading to a clear research question; then clarifies the $\mathrm{CE}$ concept in relation to the definition of manufacturing industries. A literature review follows, identifying barriers to $\mathrm{CE}$ found by other researchers; then the case study with sections on research methodology, data collection and the primary data from interviews with the 10 companies. Lastly the paper presents discussion, and a summary of findings contributing to practice and theory. 


\section{Manufacturing Industries}

This study defines manufacturing industries as the industries that use highly equipped machines and digital instruments that are helpful in their production. Examples of these kinds of industries include the construction industry, automotive industry, defence and arms industry, energy industry (electrical \& petroleum), computer industry and aerospace industry. These industries work with massive machinery, heavy metals, digital and complex mechanical instruments, drills and cranes and other heavy transport equipment and appliances (GS1, 2018). It is crucial for these industries to have a secure method to recycle or dispose of metal and electronic waste that can have hazardous effects on our environment. There have been challenges in recycling and disposing of these types of machinery and metals as they include elements and products that cannot be extracted easily.

The manufacturing sector is a cornerstone of the economy, crucial to sustainable economic growth, but the manufacturing industries are bound by tradition where change is slow and costly (Herman, 2016; Lieder and Rashid, 2016). Also, value creation is changing and customers expect value-co-creation, connectivity and sustainable operations blurring the distinction between manufacturing and services. The eireular modelCE is more complex than the linear model resulting in barriers to a move towards CE (Hopkinson et al, 2018). Companies are faced with a range of technological and cultural barriers to overcome, and for manufacturing companies, it is imperative to understand what barriers they face in order to take appropriate action. This paper presents barriers to $\mathrm{CE}$ adoption identified by a literature review, and it addresses the particular challenges faced by manufacturers expressed by the research question: What are the dominant barriers faced by the manufacturing industry in moving towards a CE?

\section{Circular Economy}

Adoption of Cireular Economy $\underline{\mathrm{CE}}$ concepts have been the focus of the food industry for several decades. Irani and Sharif (2018) explored the role of sustainable food security with closed loop business models. CE can be seen as consisting of two parts: the first part focusing on reducing the impact on the environment, and the second part focusing on creating business models that implement the first part (Torstensson, 2016). For the first part, reducing the impact on the environment, the Ellen MacArthur Foundation (2015) has given a model of circularity that shows which activity-cycles give the highest positive environmental impact. The cycles focus on a material's next use. The best next use would be to close a cycle instead of going to a cycle with lower CE effect or in to the waste-chain. Figure 1 illustrates the $M+3 R$ cycles and waste-chain. Maintaining has the highest CEimpact, followed by Reuse, Remanufacture and Recycle respectively. The waste-chain has the lowest CE-impact (Ellen MacArthur Foundation, 2015; Torstensson, 2016). The wastechain consists of Waste collectors, Energy-from-waste operators, and Landfill operators.

The ultimate CE goal is sometimes denoted a "cradle to cradle" model as described by Michael Braungart et al. (2007). This is a holistic model that seeks to create systems that are essentially waste free. In principle, products and its constituent and parts are used in a

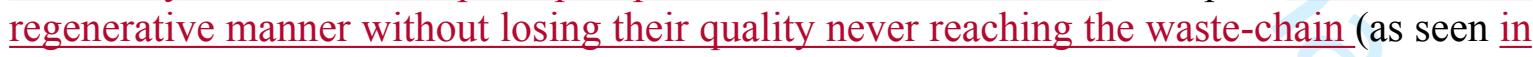
the lower part of Figure 1). This CE model is linked with the industrial ecology (IE) concept that challenges the current view that the industrial systems and the environment should be handled separately. The IE theory says that the industrial system is a kind of ecosystem where the materials are distributed, while energy and information-flow take place through the assistance of the biosphere. Hence, IE argues that the industry and environment cannot be separated from each other (Erkman, 1997; Liakos et al.). 


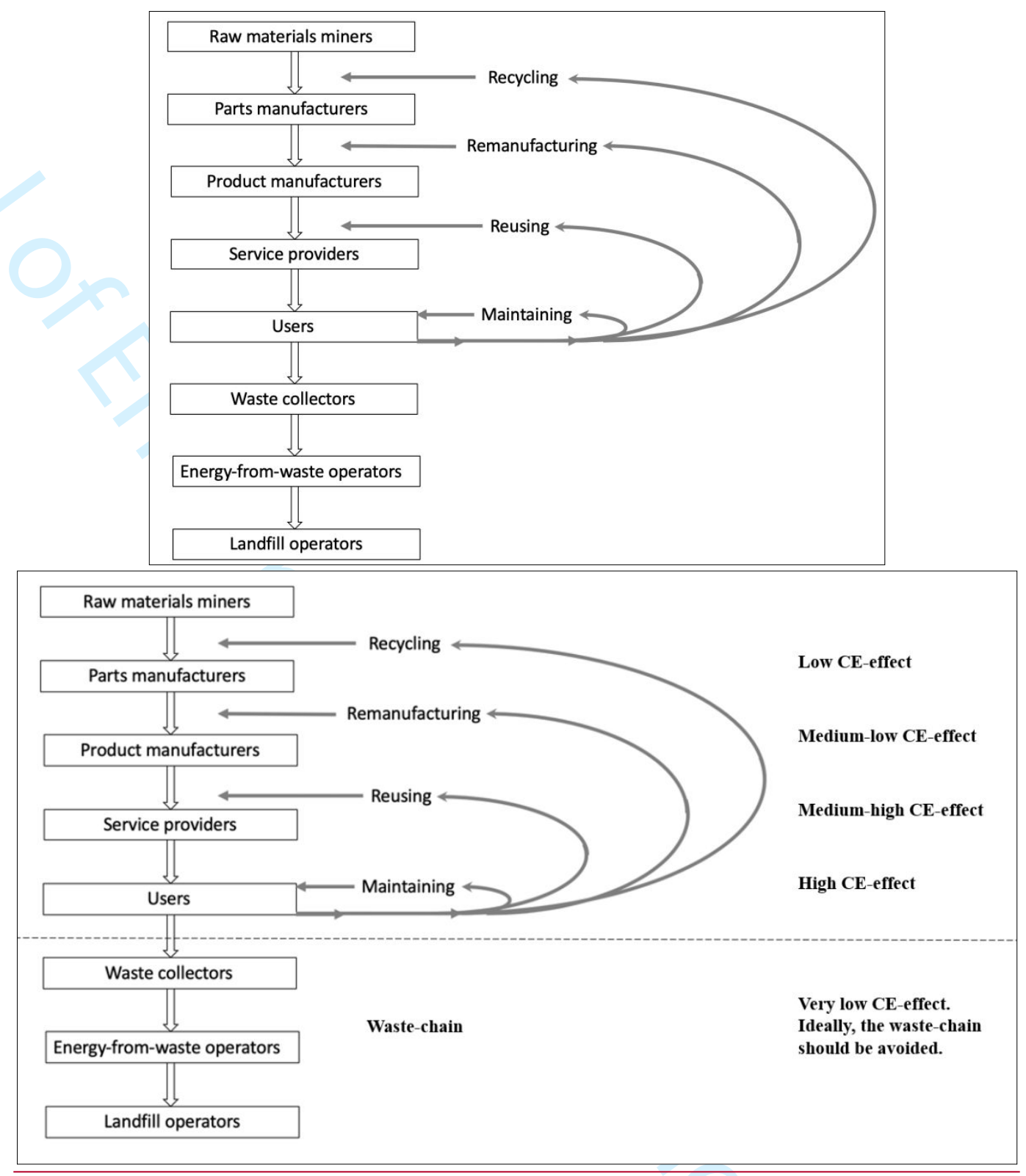

Figure $1 \mathrm{CE}$ as a restorative system for technical products with the $\mathrm{M}+3 \mathrm{R}$ cycles in the upper part and the waste-chain in the lower part (adapted from fEllen MacArthur Foundation, 2015)

According to Zhijun \& Nailing (2007), shifting towards a eircular economy $\underline{\mathrm{CE}}$ model requires a deep focus on raw materials and energy. When producing a product, the focus should be on minimizing the entire product life cycle's negative effects on the environment from the very early stage of material extraction towards the product disposal. Bocken et al., (2016) describe how to adapt product design and business model strategies to a CE. CE activities require new business models in which one pursues the opportunities for a shift from an 'end-of-life' focus to a cradle-to-cradle cycle, from using un-renewable energy towards using renewable, from using toxic chemicals to their elimination, from waste to eliminating waste by design of materials, products, systems and business models (Ellen MacArthur Foundation, 2013; Torstensson, 2016). This implies that ideally, there should be no waste, avoiding the waste-chain completely. According to Ellen MacArthur Foundation (2013), business models involving servicification are central to achieve this. 
Industrial ecology (IE) challenges the current view that the industrial systems and the environment should be handled separately. The industrial ecology theory says that the industrial system is a kind of ecosystem where the materials are distributed, while energy and information-flow take place through the assistance of the biosphere. Hence, IE argues that the industry and environment cannot be separated from each other. Industrial ecology has three perspectives. The first perspective is about the detailed view of the industrial economy and its connection with the biosphere. The second perspective covers the materiat and energy flow inside and outside the industry. The third perspective gives the proactive approach i.e. technological dynamics and shift of linear industrial systems towards industriat ecosystems (Erkman, 1997).

\section{Barriers to CE}

A shift to the CE model or any other business models for sustainability of the economy requires a dramatic change for the whole company including all the stakeholders. This shift is somewhat disruptive in nature because the current mode of working would also be changed due to the new solution of the CE model (Ritzéna \& Sandström, 2017).

Table 1 summarises the barriers in implementing the CE model found by Preston, 2012; Lit \& Bai, 2014; Eijk, 2015; Torstensen, 2016; Berchiceind Bolewes, 2005.

In order to obtain more in-depth answers to the research question, we link the barriers seen by manufacturers with barriers identified in the research literature. In this research, there are three parts:

1. To identify barriers to $\mathrm{CE}$ in the research literature

2. To identify barriers to CE experienced by manufacturers

3. To classify the barriers identified by companies according to barriers found in literatures

The first part is

In order to obtain more in-depth answers to the research question by linking findings by manufacturers with existing literature on barriers to CE. For this, an, an-exploratory review of the existing literature has been undertaken. the existing literature has been undertaken. The academic databases such as Google Scholar, Scopus, ProQuest and ScienceDirect were used. Keywords such as "Circular Economy, Product Identification, Sustainability, and Barriers to Circular Economy" were used. In the main, White-white papers, Reportsreports, gGovernmental publications and scientific journals were used as secondary data. Table 1 summarises the barriers in implementing the CE model found by Preston, 2012; Liu \& Bai, 2014; Eijk, 2015; Torstensson, 2016; Berchicci and Bodewes, 2005.

\section{Table 1: Identified Barriers in literature}

\begin{tabular}{|l|l|l|}
\hline Barrier & Description & References \\
\hline $\begin{array}{l}\text { Resource- } \\
\text { intensive } \\
\text { development } \\
\text { models }\end{array}$ & $\begin{array}{l}\text { Traditional models are highly resourced intensive; less } \\
\text { resource intensive models are lacking. }\end{array}$ & $\begin{array}{l}\text { Preston, } \\
2012\end{array}$ \\
\hline $\begin{array}{l}\text { High start-up } \\
\text { costs }\end{array}$ & $\begin{array}{l}\text { In the long run, the CE model would show sustainable } \\
\text { benefits and increased growth. But in the short run, the } \\
\text { start-up costs are high involving e.g. retooling machines, } \\
\text { relocating factories, building new distribution and logistics } \\
\text { arrangements, and retraining staff. Lack of budget towards } \\
\text { the CE model innovation. Lack of industrial symbiosis is }\end{array}$ & $\begin{array}{l}\text { Pai, 2014, } \\
\text { Eijk, 2015, } \\
\text { Torstensson, } \\
2016\end{array}$ \\
\hline
\end{tabular}




\begin{tabular}{|c|c|c|}
\hline & $\begin{array}{l}\text { a barrier towards CE because it is costly. Quality assurance } \\
\text { for recycled material to be handled in a good manner is } \\
\text { costly. }\end{array}$ & \\
\hline $\begin{array}{l}\text { Complex } \\
\text { supply chains }\end{array}$ & $\begin{array}{l}\text { Since production and consumption often take place in } \\
\text { different countries, supply chains may need to be } \\
\text { reorganized to facilitate reuse and remanufacturing. } \\
\text { Incentives throughout the supply chain are needed for } \\
\text { companies to actively consider sustainable materials, } \\
\text { durability and reparability. For the CE transition, the } \\
\text { existing network should support switching between } \\
\text { transportation modes. }\end{array}$ & $\begin{array}{l}\text { Preston, } \\
2012 \\
\text { Eijk, } 2015\end{array}$ \\
\hline $\begin{array}{l}\text { Challenging } \\
\text { B2B } \\
\text { cooperation }\end{array}$ & $\begin{array}{l}\text { A barrier is coordination across companies because it } \\
\text { needs multiple companies to adjust their daily operations. } \\
\text { This potentially gives large transaction costs and delays in } \\
\text { negotiating among companies. } \\
\text { Industrial symbiosis requires information exchange to get } \\
\text { knowledge of material and energy flows whichflows, } \\
\text { which is costly or difficult. }\end{array}$ & $\begin{array}{l}\text { Preston, } \\
2012, \text { Eijk, } \\
2015\end{array}$ \\
\hline $\begin{array}{l}\text { Innovation } \\
\text { diffusion } \\
\text { challenge }\end{array}$ & $\begin{array}{l}\text { It is critical that new breakthroughs rapidly find their way } \\
\text { into the mass market, so that transition to the CE can } \\
\text { contribute to tackling climate- and water-related goals in } \\
\text { the necessary timeframe. }\end{array}$ & $\begin{array}{l}\text { Preston, } \\
2012\end{array}$ \\
\hline Structural & $\begin{array}{l}\text { Innovation and flexibility are restricted by organizations` } \\
\text { hierarchical patterns. CE`s strategies are affected by the } \\
\text { managers' employment term restrictions. }\end{array}$ & $\begin{array}{l}\text { Liu \& Bai, } \\
2014\end{array}$ \\
\hline Contextual & $\begin{array}{l}\text { Competition in the market place restricts the movement } \\
\text { towards CE. }\end{array}$ & $\begin{array}{l}\text { Liu \& Bai, } \\
2014\end{array}$ \\
\hline Cultural & Managers are risk-averse. & $\begin{array}{l}\text { Liu \& Bai, } \\
2014\end{array}$ \\
\hline $\begin{array}{l}\text { Restricted } \\
\text { supply chain }\end{array}$ & $\begin{array}{l}\text { There is a lack of enablers to improve cross cycle and } \\
\text { cross-sector performance. Lack of exact knowledge of the } \\
\text { composition and origin of materials used. }\end{array}$ & Eijk, 2015 \\
\hline $\begin{array}{l}\text { Lack__ of } \\
\text { industrial } \\
\text { symbiosis }\end{array}$ & $\begin{array}{l}\text { Industrial symbiosis is based on having good knowledge } \\
\text { of material and energy flows within an industrial sector } \\
\text { and geographical area. It requires an exchange of } \\
\text { information regarding inputs and output to optimize the } \\
\text { processes, but this industrial symbiosis is a barrier towards } \\
\text { CE because it is costly or difficult to obtain. }\end{array}$ & Eijk, 2015 \\
\hline Logistics & $\begin{array}{l}\text { Information exchange systems in logistics are limited. } \\
\text { Cargo flows are handled by logistics, which also includes } \\
\text { the reverse logistics and supply chain management. For the } \\
\mathrm{CE} \text { transition, existing network design is a barrier. The } \\
\text { design should support switching between transportation } \\
\text { modes. }\end{array}$ & Eijk, 2015 \\
\hline $\begin{array}{l}\text { Lack of } \\
\text { information } \\
\text { on Product } \\
\text { product } \\
\text { design and } \\
\text { production }\end{array}$ & $\begin{array}{l}\text { Removing of toxic material and separation of biological } \\
\text { from the technical substance is lacking. Shortage of } \\
\text { information regarding green suppliers. Current product } \\
\text { design is given less attention towards the end phase of } \\
\text { products. }\end{array}$ & Eijk, 2015 \\
\hline
\end{tabular}




\begin{tabular}{|c|c|c|}
\hline Recovery & $\begin{array}{l}\text { The products are becoming more complex; the recovery of } \\
\text { such products is a big challenge. }\end{array}$ & Eijk, 2015 \\
\hline Recycling & $\begin{array}{l}\text { Recycled materials are sometimes more expensive than the } \\
\text { new raw materials. Investing in recycling is seen to be } \\
\text { risky on a larger scale. }\end{array}$ & Eijk, 2015 \\
\hline $\begin{array}{l}\text { Lack of } \\
\text { technical } \\
\text { skills }\end{array}$ & $\begin{array}{l}\text { A barrier towards the implementation of CE is the lack of } \\
\text { skills in small and medium-sized enterprises. They do not } \\
\text { realize the benefit of implementing more advanced } \\
\text { technologies that reduce the negative impacts on the } \\
\text { environment and would give them costs savings. }\end{array}$ & $\begin{array}{l}\text { Rizos et al., } \\
2015\end{array}$ \\
\hline $\begin{array}{l}\text { Quality } \\
\text { compromise }\end{array}$ & $\begin{array}{l}\text { Companies' reluctant attitude towards CE is their concern } \\
\text { regarding the quality of materials. They fear materials } \\
\text { would be chosen based on the environmental aspects } \\
\text { instead of the quality of performance. }\end{array}$ & $\begin{array}{l}\text { Torstensson, } \\
2016\end{array}$ \\
\hline $\begin{array}{l}\text { Disassembly } \\
\text { of products is } \\
\text { time- } \\
\text { consuming } \\
\text { and } \\
\text { expensive }\end{array}$ & $\begin{array}{l}\text { A product is made of many different components which } \\
\text { are attached in a way that their disassembly is hard and } \\
\text { time-consuming and it seems much better to produce a } \\
\text { new product than to recirculate the materials, and also it } \\
\text { would be very expensive to mould the components in a } \\
\text { way they could be available to use again. }\end{array}$ & $\begin{array}{l}\text { Torstensson, } \\
2016\end{array}$ \\
\hline $\begin{array}{l}\text { No surety CE } \\
\text { will help the } \\
\text { environment }\end{array}$ & $\begin{array}{l}\text { Companies cannot be sure that recycling, remanufacturing } \\
\text { and reusing will save money or protect scarce resources, } \\
\text { and it might be the case that producing a new product is } \\
\text { less costly than reusing the old one. }\end{array}$ & $\begin{array}{l}\text { Torstensson, } \\
2016\end{array}$ \\
\hline $\begin{array}{l}\text { Quality } \\
\text { assurance }\end{array}$ & $\begin{array}{l}\text { A barrier is that it is difficult to know what has exactly } \\
\text { been done with the material and whether the recycled } \\
\text { material is handled in a manner that is good with respect } \\
\text { to quality, and all these things involve costs. }\end{array}$ & $\begin{array}{l}\text { Torstensson, } \\
2016\end{array}$ \\
\hline $\begin{array}{l}\text { Design } \\
\text { irrespective } \\
\text { of CE }\end{array}$ & $\begin{array}{l}\text { The products that are produced lack a circular design } \\
\text { which is the reason the reusing, disassembly, } \\
\text { remanufacturing etc. is hard. }\end{array}$ & $\begin{array}{l}\text { Berchicci } \\
\text { and } \\
\text { Bodewes, } \\
2005\end{array}$ \\
\hline $\begin{array}{l}\text { Hygienic } \\
\text { issues }\end{array}$ & $\begin{array}{l}\text { Some perceive that recycled or reused materials are not } \\
\text { safe and hygienic. }\end{array}$ & $\begin{array}{l}\text { Berchicci } \\
\text { and } \\
\text { Bodewes, } \\
2005\end{array}$ \\
\hline
\end{tabular}

Research Methodology

\section{Data Collection}

This study uses a qualitative approach method using data from semi-structured interviews. According to Yin (1994, pp.19) research design is the action plan to help a researcher execute the research from its inception to its conclusion. It does this by providing the researcher with "the initial set of questions to be answered, and there is some set of conclusions (answers) about these questions" (Yin, 1994). A c Case study approach was adopted as the primary research method for data collection. The case study approach as a research method for data collection is being widely used as a "common research strategy in psychology, sociology, political science, business, social work, and planning" as it has the potential to make unique contributions "to our knowledge of individual, organisational, social, and political phenomena" (Yin, 1994, pp.2). The unique characteristic of the case 
study approach is the ability to acquire and "retain the holistic and meaningful characteristics of real-life events" (Yin, 1994, pp.2) which can be of tremendous importance in any sociological research study. To fill the gap in research on a limited understanding of the barriers of a eireular economy $\underline{\mathrm{CE}}$ for manufacturing companies - a multiple exploratory case study approach was adopted as the primary research method for collecting data.

Our primary data are obtained through the use of semi-structured interviews from manufacturing companies. Qualitative semi-structured interviews are one of the most dominant and widely used methods of data collection within the social sciences (Bradford \& Cullin, 2012). Interviewing the-specific companies who work with technical parts of machineryindustrial manufacturing and foeus on the idea of green supply chain and sustainability, has-given knowledge on an idea about their approach towards sustainability and the CE concept. internal capacities, internal problems and barriers that they encounter each day by handling those products. The ideas and views given by the companies were observed and analysed through an interpretive measure. Our interpretation leading to the identification of barriers as seen by manufacturers are based on the subjective perceptions of the employees interviewed at each company. This gives an indication of what barriers they face. Specifically, we attributed statements in the interviews to barriers already identified in the research literature (summarized in Table 1). For example, for company 1 , the authors asked the question regarding the circular economy. The respondent said that almost $95 \%$ of the engine parts and equipment are recycled and have high quality but the main barrier is the cost of recycling. From this, we find that company 1 face the barrier "High start-up costs". This classification is summarized in Table 2 for all companies. Since we investigate a social phenomenon, our qualitative analysis of the interviews is based on our interpretive classification. It was not codified or statistically analysed. This approach satisfies our goal by this research in classifying the barriers to CE transition according to the companies' point of view with the barriers derived from the literature. The ideas and views given by the company are observed and analysed through an interpretive measure and inferences depend on the subjective perceptions of the employees working in the hierarchy.

\section{Interview execution}

During the interviews, notes were taken to avoid the loss of important information. The Interview interview guide was changed a little, based on the participant company i.e. some questions were added for GS1 Company and the context of one interview guide needed to be amended for another._It would be noted that Five whilst the majority of interviews took place face to face, four by phone, and, one interview had to be conducted-via email.

\section{How Qualitative Data Analysis is done}

For a detailed analysis of primary data, a general analytical procedure was conducted. For the purpose of qualitative analysis and getting a true picture of the interviews, they are transcribed. In transcription, special attention has been given to accuracy by focusing on the shortening of sentences and elimination of words that were repeated. Coding is used on transcripts to make the data accurate and precise. Coding is the method of reading the text carefully and considering all the meanings in the text and making categories (Thomas, 2006).

\section{Companies interviewed: 10. Total number of persons: 14}

To identify barriers to CE by manufacturers we made a list of manufacturers in Norway from which we selected 10 companies of various size, from small companies with a modest turnover and tens of employees; to large multinational companies with billions in turnover and thousands of employees. This would get us a broad overview acrossof 
companies of various sizes. The interviews were conducted by approaching persons who have deep knowledge of the operation of the company. We selected companies with head offices in Norway since this research is part of the Manufacturing Networks 4.0 research project funded by the Norwegian Research council. As all of the companies have extensive international operations with global reach, the information collected is considered to be representative forof manufacturing companies in general.

Companies 1, 2, 3, 4,5 and 6 were big, multinational companies all having a sustainability strategy in place communicated throughout the company via top management and dedicated corporate social responsibility (CSR) staff. The authors anticipated top-level managers to be well aligned with the stated company strategy on sustainability and CE. Thus, mid-level management were targeted for the interviews, as this would give an insight on how well the strategy is communicated in each company.

The smaller companies had no documented strategy for sustainability or CE, i.e. companies 7,8,9 and 10. Since, in small companies the communication among employees are more direct and verbal, senior management representatives were selected for interviews.

The Interviews were conducted by approaching persons who have deep knowledge of the operation of the company. For the smaller companies [companies 7, 8, 9 and 10], this was typically someone from senior management. For the bigger, multinational companies, the persons interviewed were typically mid-level managers or senior consultants. The bigger companies all had a sustainability growth policy in place which was well communicated inside the company via a Corporate Social Responsibility (CSR) type organisational role. Top level management is expected to be aligned with their strategy and produce yearly statements focusing on sustainability, so for these companies we targeted mid-level management to get an indication of how well the top-level strategy propagated through the eompany.

Company 1 is a manufacturer of marine products like engines, power systems and digital elements for marine vessels with an annual turnover of 919 mAillion Eureeuro (2017). It is the marine subsidiary of a global manufacturer of power and propulsion systems for use on land, at sea and in the air. Their corporate environmental strategy promoted through their annual report from 2017 focuses on reducing the environmental impact, developing low emission products, and reducing the impact of business operations. The person interviewed was a supply chain manager responsible for the flow of material in and out of the company. The company seeks to minimise its effect on climate change through a low carbon strategy; a corporate goal to reduce environmental impacts from-of production, $;$ and a commitment to improving improve the environmental performance of its products. Furthermore, they are strongly committed to health, safety and environmental management. The respondent said: "We don't exactly use the term circular economy, but we have all the focus on environmental protection. We have a programme called Revert which is about minimizing the demand for the new materials in which the metals are being recycled."-This also helps in lowering the cost and reusing of finite resources i.e. rhenium, hafnium, nickel and titanium.

On the question regarding the eireular economy $\mathrm{CE}$, the respondent confirmed almost $95 \%$ of the engine parts and equipment are-can be recycled, but . He said the main barrier is the cost of recycling. Through the Revert programmeprogramme, tons of carbon dioxide are saved compared to using new materials. In addition to the cost of recycling, another barrier the respondent mentioned was the disassembly of the products.

It is evident from their strategic goals and the interview that company 1 has a focus on the mid to lower impact CE strategies of recycling (ref. Figure 1) from a general $\underline{\text { environmental perspective, and with no specific reference to } \underline{\mathrm{CE}} \text {. Thus, company } 1 \text { has less }}$ 
focus on the high impact aspect of CE such as engineering of new products with maintenance and reuse in mind. The barriers of cost and disassembly mentioned earlier reflect this.

Company 2 is a manufacturer of professional lighting solutions for the onshore and offshore global market with an annual turnover of $236 \underline{\mathrm{m} M i l l i o n}$ Euroeuro (2017). The persons interviewed were their chief technical officer and head office group IT-manager. Their goal towards a sustainable environment is:

"The total products that come to the end, do not end but they are used again to make something new. The main objectives of the company are; reducing wastes, diminishing energy utilisation, expanding reuse of products, environmentally efficient transport solutions and prohibiting emissions."

By law, The the company is required by law to follow local and global standards and environmental policies, which is reflected in one of the answers from the employee:

"Our company's products also satisfy the WEEE Directives (Waste Electrical and Electronic Equipment). It has ISO 14001 environmental certification and policy for Corporate Social Responsibility (CSR) to support a precautionary approach to environmental challenges, undertake an initiative to promote greater environmental responsibility and support the development of environmentally friendly technologies."

The interviewees mentioned several barriers to implementing CE. These were: In addition to sustainability, the technological barriers to implementing Circular Economy were discussed. These include: littlelittle attention towards end-phase of the product; difficulty in disassembly due to the need to separate biological substances from technical products; difficulty in reusing the products; recycled materials being more expensive than new materials; recycling taking more time than using new materials; the potential reduced quality of recycled materials; and mixing recycled and new materials increaseing supply chain complexities. attention towards end-phase of the product; separation of a biological substance from technical products are lacking due to missing information; difficulty in reusing the products due to complex nature of products; recycled materials being more expensive than the real/virgin materials; consuming more time; quality issues and supply ehain complexities. Of these, the main barriers identified were the quality issue and disassembly of products. Including used parts in a product might result in reduced quality of the final product since the reused parts may not be equally good as virgin parts. In addition, it might be hard to disassemble products and verify whether the recycled parts meet new standards.

National and international directives for electronic equipment implemented over the last few decades have dominated eThe quality issue and disassembly of products were the main barriers that they face because the reused products may not be as good as virgin products that meet new standards. To produce (remanufacture) more quality products from recycled materials, it needs to be a more accurate process when extracting those parts while recycling. company 2's efforts toward environmental aspects. The directives target the linear model handling the end-phase of a product as waste, possibly after being recycled or "downcycled" into products with less CE-impact before ultimately becoming waste (Figure 1). In this regard, the company has not yet achieved all it can, additional circularity considerations including product design considerations at an early stage of product design and material $\underline{\text { selection to support a cradle-to-cradle model. }}$

Company 3 is the global standardisation organisation GS1 (Global Standards 1). This company preferred not to be anonymous since promoting standards that help companies move towards sustainable operations are a part of their strategy (GS1 2018). GS1 is the leading global standardisation organisation in business-to-business trade best known for the 
barcode and RFID standards. Any company marking its product with a barcode needs to get it from GS1.GS1 has an office in most countries worldwide. In Norway, more than 6300 companies are registered at GS1 giving. Thus, GS1 ean be seen to have-a good overview of standards used by companies including the ones used by-manufacturers-as the identification of components and equipment enables efficient manufacturing processes. The procurement, storage, assembly, maintenance, repair and disposal of products and their components can be optimised based on GS1 identification standards. GS1 Norway has fifteen employees. We interviewed Terje Menkerud, a senior advisor at GS1 This interview was conducted-in the Department of Delivery Standards-where we interviewed Terje Menkerud, a senior adviser at GS1. The respondent stated that the company`s deeply committed to sustainabilityRegarding challenges to manufacturers with respect to sustainability the respondent said:

"We don't focus on circular economy per se but everything we do is based on sustainability and environmentally friendly ways of doing things and GS1 has focused on carbon footprints. .... Everything we have done has the circular economy approach applied. Everything we do is based on sustainability, efficiency and an environmentally friendly way of doing things not just in transport and logistics, but in everything we do from the healthcare sector, retail, and apparel sector to logistics sector. GSI is not a logistics company, it came from the retail sector and not many companies see us as a logistics company. This is the biggest challenge to get the actors and the players in the field of logistics to know who we are and raise awareness of our system and get to know how we could help them in daily business by reducing the cost and solution towards environmentally friendly transportation."

He further explained that that since a lot ofmany players in the market have their own proprietary systems for identification of products leading to B2B cooperation being a big challenge, especially when combined with the complexity of supply chains. GS1 standards can help companies in extracting the harmful substances by giving companies a specific identifier to each of their products and each component. The lack of product information about product design and production is a barrier since the company need accurate information for cost efficient recycling, reusing, repairing and systems, they do not interact effectively. If you receive some material from another market you have to re label it. To get the entire community into the same global standardized way of trace and track with unique identification is-cost efficient disassembly of products. He stated:

a big challenge in a way of sustainability. This is aligned with the challenging $B 2 B-$ eopperation identified in the literature review. The respondent explained that "Cireular economy" is

"A way to reuse resources" and for transport "Is the reuse of pallets; reuse of containers; reuse of what the transport is done with". We don't focus on circular economy per se but everything we do is based on sustainability and environmentally friendly ways of doing things and GS1 has focused on carbon footprints. GS1 would not accept that our system is used in a way that is not for the greater good. Everything we have done has the circular economy approach applied. Everything we do is based on sustainability, efficiency and an environmentally friendly way of doing things not just in transport and logistics, but in everything we do from the healthcare sector, retail, and apparel sector to logistics sector. A product attribute in the standards supports recycling to be registering what the product consists of, and how these products can be treated in a special way and how to recycle them. tabels related to environmental sustainability are put on the products. Not all these attributes are mandatory so not all producers are using it."

Further details of the questions and answers for GS1 can be found in Naz and Rahim (2018). A product attribute in the standards supports recycling to be registering what the product consists of, and how these products can be treated in a special way and how to recycle them. Labels related to environmental sustainability are put on the products." 
It is evident that digitalization and information management of individual products is required for manufacturers to move towards a CE model in a cost efficient manner. Barriers of supply chain complexities, business to business (B2B) cooperation, lack of information in product design and production, fear of compromising performance quality if environmental aspects are included, and prohibitive costs for disassembly can all be mitigated by proper information management founded on global standards.

Company 4 is a world-leading manufacturer of aluminium with an annual turnover of 3.9 $\underline{b}$ Billion Eureeuro. We conducted two This is one of the largest companies in Norway. Tw different interviews-were conducted with two persons, one at the corporate head office and one at a production plant. The respondent at the head office, a SAP consultant working on implementing the procure-to-pay process, had very good knowledge of the concepts of sustainability and eireular economy $\underline{\mathrm{CE}}$. He stated (translated from Norwegian):

"We are focused on sustainability towards our customers, and also for our internal processes. As an example, we focus on the recirculation of used aluminium because recirculation requires only 5\% of the energy compared with producing new aluminium. We invest heavily in green technologies in Norway using renewable hydropower and advanced technology with lower energy consumption and low emissions. We cannot compete on price with manufacturers in low cost countries like China and Russia, instead, we target climateconscious consumers by providing the lowest low carbon footprint in the market branded as Aluminim 4.0 products. These products are certified by the Almminim Stewatship Initiative (ASI) as well as the ISO 14064 (Greenhouse gases) certification."

Regarding barriers to CE adaption, the respondent said "The cost element is always a challenge. We need to balance the trade-off between investment and earnings."

The other respondent at the production plant as a senior accounting consultant had less in-depth knowledge of sustainability and eireular economyCE. He stated:

"Even if we do not use these terms on a daily basis, we focus a lot on the reuse of metal related to the production. When the products are cut according to the preferences of customers, there will be left-over pieces and metal shavings. The pieces are melted, and the shavings are sold to others. Also, slag from the ovens contains valuable metals that are sold to other companies."

Regarding barriers to CE adaption, the respondent said: "I am not sure, most of the focus is on energy-efficient production, and some smaller initiatives on the separation of general waste for recycling".

At GS, there is a clear understanding of the importance of CE at the head office showing that overall corporate CE strategy is well communicated at the central management level, while being less more focused on specific operational issues related to implementing CE aspects at the plant level.

Company 5 is a manufacturer of furniture with an annual turnover of 220 Million Euremillion euro. One interview was conducted with two persons at the corporate head office. One was Corporate Social Responsibility (CSR) Manager and one was e-commerce Coordinator. Both had very good knowledge of the concepts of sustainability and eireular economy $\mathrm{CE}$. The e-Commerce Coordinator stated (translated from Norwegian):

"We have conducted projects on sustainability in logistics, in marketing and in business operations where we have studied various circular economy models. We looked at deposit based systems for recycling furniture for the second hand market, how to approach our communication for this to create a positive effect for the company, and so-on. In logistics, we actually tested a sharing economy concept using a distribution hub with good results." 
Regarding barriers "We move in this direction, but traditional supply chain structures hinder e.g. direct distribution avoiding intermediaries. Another aspect is the cost of making second-hand-friendly products versus getting payback for doing it."

CE adaption at company 5 focuses on the business model, how to be paid for the cost of turning the value chain towards re-usable furniture. The lock-in at the linear manufacturer - retailer - customer business model is a barrier. They explained that the role of retailers is diminishing, while e-commerce to end-customers are increasing in the market. The B2Bcooperation is challenging. Existing retailer contracts hider a smooth transition from the old to the new model, and it is too risky to make a disruptive move leaving out the retailers. The costs might be too high in changing to e-commerce trade channels.

The CSR Manager stated "An important factor in our work on circular economy is that our customers increasingly demand information on the environmental footprint of our products. Both end customers and especially retailers have strong requirements, e.g. connected to the use of chemicals. Internally, we have a strong tradition for the efficient use of resources following a lean approach. As an example, scrap from leather cutting is resold to manufacturers of smaller items like key holders, and we use wood remains to heat our factories and even a building with 30 apartments and a swimming pool."

Regarding barriers to $\mathrm{CE}$ adaption, tThe respondents further stated regarding barriers said- "The new regulations on public spending from 2017 requiring buyers in the public sector to weight the environmental aspect in the tendering process as well as a major criterion in the decision process has had a big effect. It has spread to the sffere oil and gas business and the hotel chains. The media is also focusing on environmental issues, and we have seen municipalities that got a lot of negative press coverage for not following the rules."

Company 5 has an increasingly complex value chain with more trade channels, more environmental related regulations and higher awareness among customers on CE issues. This company is still in its infancy in theirits transition to a CE model. Furniture has no established specific recycling value chain like for electrical products, thus at the end-phase of a product, it is treated as household waste entering the CE waste chain in Figure 1. They are aware of the markedt demand for a restorative system, but the main barriers of costs and supply chain complexities are hard to overcome. Our company follows ISO 140001 incorperating weight of envirenmental footprint aspects regarding leather, transport, etc. We move in this direction, but traditional supply chain structures hinder e.g. direct distribution avoiding intermediaries. Another aspect is the cost of making second hand-friendly products versus getting payback for doing it."

We attribute these barriers to the challenging $\mathrm{B} 2 \mathrm{~B}$-cooperation and the high-start up cost barriers.

Company 6 is a manufacturer of marine propulsion and thruster systems with an an-annual turnover of

turnover of 100 mMillion Eureeuro. We had one interview with two respondents:

One interview was conducted with two persons at the head office. One with the position aThe s-Executive Vice President of Health, Safety, Environment, \& Quality \& Sustainability (HSEQ), and while the ether was the-Manager for Product Development.

_Both had very good knowledge of the concepts of sustainability and eireular economy $\mathrm{CE}$. The company strategy is according to what they called "The green maritime shift" leading to S. The SEQ responsible stated that sustainability sustainability and CE being important is one of theirstrategic focus areas. In an internal survey by the company asking their workers, 
a little more than 50 percent responded that they know of the companies' sustainability goals. They adhere to what is called "The green maritime shift", and a strategy saying; "Production shall be in Norway".

Related to barriers they said there is a identified-risk of lower quality of some recirculated materials-components compared to new components. For example, metal parts experience structural damage when subjected to strains. There is-,-a lack of traceability for some products-in the value chain (after delivery) limiting the possibility of life cycle management, and company 6 said the immature-marked for service models like "power by the hour" are immature. Their production follows an engineer-to-order strategy with frequent changes efin product design during production resulting in-,-challenging $\mathrm{B} 2 \mathrm{~B}$ cooperation-towards supplierssince their production is project based following an engineerto-order strategy. Their Ship-owner-customers are shipyards with a strong focus on short delivery time, with less concern of speed, and less on-environmental aspects like energy consumption when during the ship's operations. Thus, so-different B2B actors are not well aligned.

Company 6 has strategies towards the green maritime shift, looking at using recycled components. Recycling has low CE-impact (Figure 1). They look at new business models like power-by-the-hour selling power instead of ship engines, which would enable optimised maintenance schemes with high CE-effect (Figure 1). However, company 6 finds that the market is not ready for such solutions yet.

Company 7 is a manufacturer of automated fish handling systems with an annual turnover of 115 Million Euremillion euro.-The person interviewed was a senior engineer working on product design. They develop, produce and install systems solutions-for use on ships and on , on land and for_aquaculture installations. The company headquarters are-is on the west coast of Norway with six subsidiaries locations-in Spain, Romania and Europe and the the USA. The respondent stated (translated from Norwegian) "- I have not used the concept of $C E$, but we have a strong focus on environmental aspects. The machinery we produce, combined with German industrial machines minimises "scrap". The machinery separate fish according to size, then process the fish, supporting the sale of left-overs to producers of emega 3 oils, etc.

The interview and web-based business communications indicate that company 7 focuses on traditional environmental issues like reducing waste. In the ideal CE-model waste should be omitted, omitting the waste-chain in Figure 1. Based on this, company 7 operates in a traditional manner with no stated strategy of moving towards a CE-model.

Company 8 is a manufacturer $\theta$ fof marine generator sets for maritime applications maritime propulsion solutions-with an annual turnover of 22 million Euremillion euro. They follow an engineer-to-order manufacturing strategy, producing tailor-made solutions. Their main business is deliveries of diesel engines, propulsion systems and generator sets for dieselelectric maritime systems. In addition, company 8 provides services for applications on express boats, ferries, and for the oil and gas industry. The-The One-interview was conducted with two persons. One was the Director of Business Development at the company headquarters, while the other and the was-Manager of Power and Propulsion Systems-at a subsidiary. They stated that they develop and patent solutions-focusing on eco-friendly and low-emission solutions using permanent-magnet technology changing from diesel engines to electrical engines. There are many environmental benefits including lower energy consumption, lower emissions, lower fuel consumption and reduced maintenance costs. Permanent-magnet motors are unique and efficient, they save space where power and torque are concerned and are relatively simple systems that can meet the strictest environmental 
requirements set for express boats and ferries. The respondents said the company We focuses on adaption to a eircular economy $\mathrm{CE}$ in ongoing business operations-for service operations en ship engines-and for the return logistics. Of challenges (barriers) they mentioned: lack of a system for reuse of batteries is a challenge in going from diesel to electric engines; lack of competence for putting CE into practice; and that new service based models are challenged by existing models.

Redesigning products to use electrical engines instead of diesel engines will have a high CE-effect as it enables other operational regimes for maintenance, reuse etc. with high CE-effect. This is a small project based company with close communication between management and operational staff enabling them to adapt fast to new market drivers.

Company 9 is a manufacturer of thermoplastic products with an annual turnover of 8 mMillion_Euroeuro. One-The interview was conducted with the managing director. He had good knowledge of the concepts of sustainability and eireular economy $\mathrm{CE}$. The respondent stated (translated from Norwegian) that they focus on recirculated products for farmed fish enclosures such as fish ponds now with a new concept using pipe-sections leaving the EPS floating pipes type of products. Some cChallenges mentioned (barriers) were how to change to manufacturing products based on recirculated materials. New service oriented business models aligned with the CE-concept, will cause a-challenges regarding B2B cooperation some are leasing fish enclosures requiring B2B cooperation for new business models. requiring new contracts and partnerships.

Company 9 concentrates on increasing its use of recycled materials, especially Expanded polystyrene (EPS), an approach with low CE

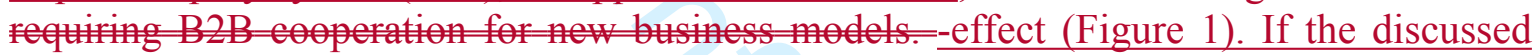
service models are realized, they have the potential to move the company towards operations with a higher CE-effect.

Company 10 is a manufacturer of industrial automation systems with an annual turnover of 3.5 mMillion Euroeuro. TOne interview was conducted with the managing director wasere interviewed. He had some knowledge of the concepts of sustainability and eireular economy $\underline{\mathrm{CE}}$, sayingsaying, "I have partial knowledge of these terms. It depends on what you mean." After clarifying this was related to the goal of environmentally friendly manufacturing, he stated "We have looked at it for BIM (Building Information Management) systems, e.g. when demolishing buildings and the need for information handling promoting reuse of components. We have also discussed using blockchains to register transported cement and gravel on ships. Several loading and unloading operations require a common register, but this is not the case today." Regarding barriers, the respondent said: "It is a cost issue; potential solutions will not get used unless there is a clear way to get profit from it. A favourable cost-benefit analysis is hard to find".

Company 10 has no strategy related to CE. They are partly familiar with the reuse of building components, an industry with a growing use of automated documentation services. If realized, the reuse of materials have a medium to high CE-effect (Figure 1).

\section{Analysis}

This chapter focuses on the data collected in the semi-structured interviews of the ten companies. Company 1 Most of the

Even if the-respondents involved in the research don 't use the words "Circular Economy", but alltheir efforts towards environmental protection and sustainability have a base in this concept. Most of the manufacturers (companies 1, 2, 3, 4, 5, 6 and 9), have identified 
activities involving recycling of products or using recycled materials as part of their production. This show they are focused on low CE-effect operations according to the CEmodel in Figure 1. None of the manufacturing companies have active business models funded on regenerative operations with high CE-effect. Thus, they lack an explicit focus on the cradle-to-cradle cycle with the ideal goal of eliminating waste by design of materials, products, systems and business models.

The barriers identified reflect this. For example, regarding the barrier "high start-up costs, the respondent in company 2 mentioned, "recycling is more expensive than the virgin materials". Here, the respondent focused on recycling and the cost barrier. Company 2 overtly recognises its goal towards a sustainable environment and the necessity of charging their customers a small recycling fee that is transferred to the recycling funds to handle recycling. Company 2 has membership in an association of recycling companies that make sure electronic product waste is handled carefully and that products are reused instead of new raw materials. By doing this energy consumption is saved, and environmentally friendly products are produced by reducing the global waste. The company is also certified with ISO 14001:2004. This enables the company to comply with the rules and regulations of the environmental management system thereby reducing the negative effects on the environment.

In the same manner, regarding the barrier of "complex supply chains", all respondents said that the disassembly of products is not easy. The large manufacturing companies (companies 1-6) have written strategies that give special attention to regeneration of resources, and they have special programmes to implement such concepts as illustrated by the "Revert project", the "sunshine program" etc. These regenerative actions for e.g. aluminium and expanded polystyrene (EPS), are a form of recycling requiring with high demand for energy. Thus, they focus onrecycling, and not reuse or maintenance. Similar reasoning were found for the remaining barriers identified, i.e. "challenging B2B cooperation", "lack of information in product design and production", "lack of technical skills, quality compromise", and "disassembly of products is time consuming and expensive". Large manufacturing companies give special attention to regeneration of resources, and they have special programmes to implement such concepts as illustrated by the "Revert project", the "sumshine program" etc.

Company 2 overtly recognises its goal towards a sustainable envirenment and the necessity of charging their customers a small recycling fee that is transferred to the recycling funds to handle recycling. Company 2 has membership in an association of recycling companies that make sure electronic product waste is handled carefully and that products are reused instead of new raw materials. By doing this energy consumption is saved, and environmentally friendly products are produced by reducing the global waste. The company is also certified with ISO 14001:2004. This enables the company to comply with the rules and regulations of the environmental management system thereby reducing the negative effects on the environment. There are a lot of differentbarriers identified mentioned in the literature review section (Table 1) varies, ehapter. Ssome are general barriers, and some are related to the supply chain. The re are different-barriers identified by the companies whom-we have interviewed mostly. Most of the barriers-focus on the supply chain in generat-and productrelated barriers in particular. The next section summarise Based on our analysis, the barriers authors identified based the interviews with manufacturers. have identified barriers for moving towards a $\mathrm{CE}$. We provide recommendations to the companies in manufacturing industries that are in need of strategies for handling the transition to a regenerative model adhering circularity of the CE model. 
Barriers identified to the $\mathrm{CE}$ in manufacturing industries

Based on the results in the "The manufacturing companies investigated are-all aware of the growing importance of the environmental aspects mentioning efforts to increase reuse, lower $\mathrm{CO}_{2}$ emissions and reduce waste. Our investigation shows that the transition from traditional environmental considerations towards circular models face several barriers.

\section{Company 1}

Even if the respondents involved in the research don" the "Cincular Economy",

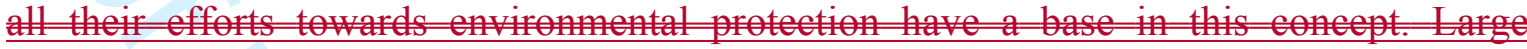

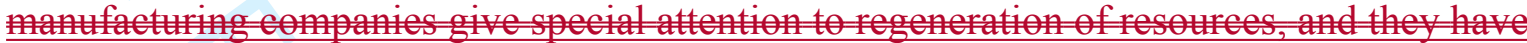

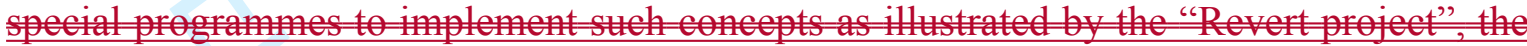
"sunshine pram"

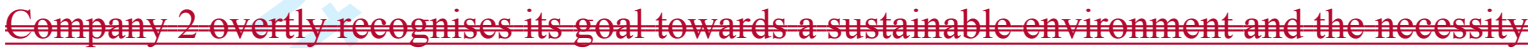
of charging their eustomers a small recying fee that is transferred to the recying fundsto handle recling. Company 2 has membership in an association of recying companies that make sure electronic poluet waste is handled arefly and that polucts are reused insteat of new raw materials. By doing this energy consmpion is saved, and envimenmentally friendly product are produce by reducing the global waste. The company is also entified With ISO 14001:2004. This nables the company to comply wh the rules regutans of the envirenmental management system thereby reducing the negative effects on the

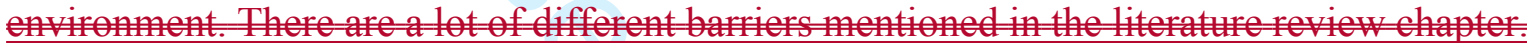
Some are general barriers, and some are relate the supply chain. There are different barriers identified by the companies whom we have interviewed. Most of the barriers foeus on the supply chain in general and product related barriers in panticular.Figure 2 shows the barriers identified by the companies. In addition to this, Table 2 presents the barriers identified by companies and in literature providing a comparison.

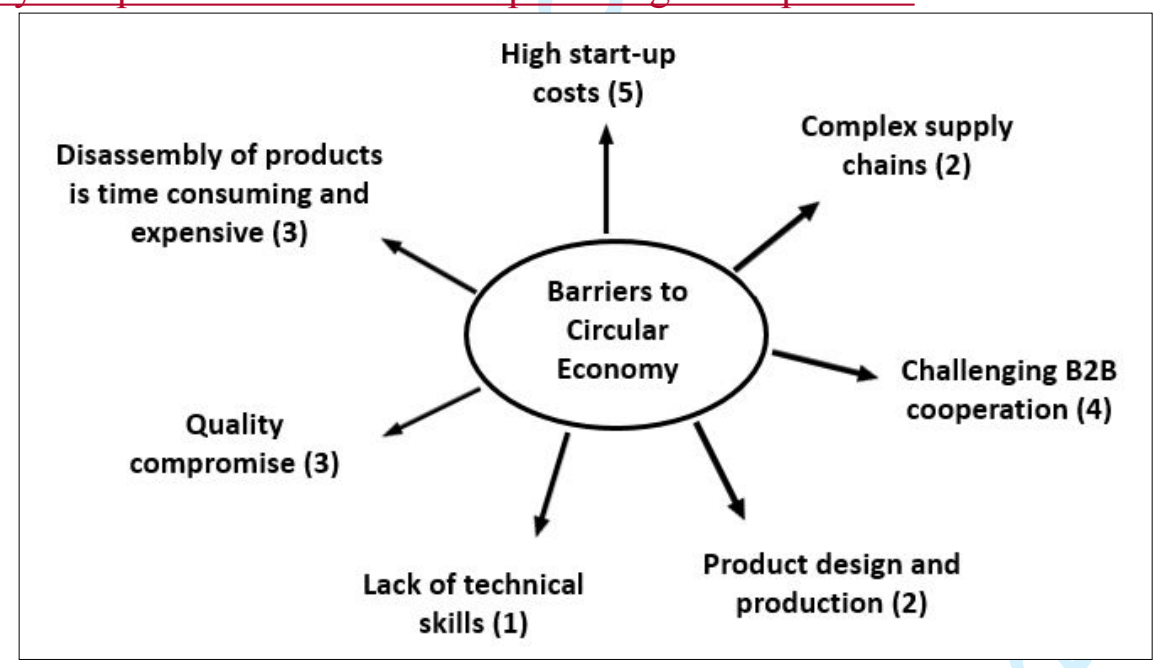

Figure 2 Barriers identified by companies (the number of companies identifying each barrier in parentheses)

Data Collection" and the "Analysis" sections classify the barriers to fit with barriers identified in the literature. This classification is summarized in Table 2 for all companies.

Table 2: Barriers in literature and by companies

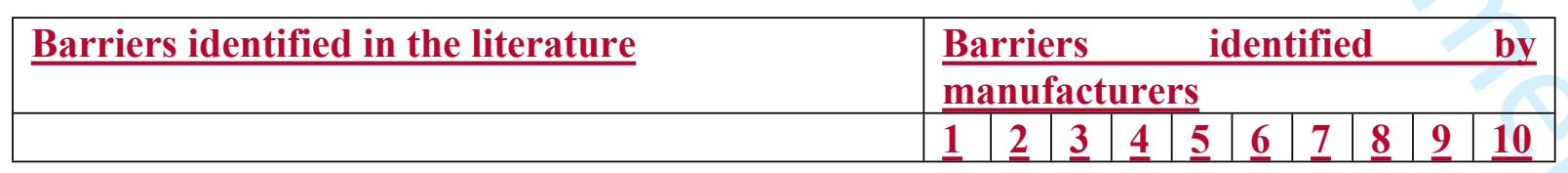




\begin{tabular}{|c|c|c|c|c|c|c|c|c|c|}
\hline \multicolumn{10}{|l|}{ Resource-intensive development models } \\
\hline High start-up costs & $\underline{v}$ & & $\underline{v}$ & $\underline{v}$ & $\underline{v}$ & & & & $\underline{v}$ \\
\hline Complex supply chains & & & $\underline{v}$ & & $\underline{v}$ & & & & \\
\hline Challenging B2B cooperation & & & $\underline{v}$ & & $\underline{v}$ & $\underline{v}$ & & $\underline{v}$ & \\
\hline Innovation diffusion challenge & & & & & & & & & \\
\hline Structural & & & & & & & & & \\
\hline Contextual & & & & & & & & & \\
\hline Cultural & & & & & & & & & \\
\hline Restricted supply chain & & & & & & & & & \\
\hline Lack of industrial symbiosis & & & & & & & & & \\
\hline Logistics & & & & & & & & & \\
\hline Lack of information on product design and production & & & $\underline{v}$ & & & & & $\underline{v}$ & \\
\hline Recovery & & & & & & & & & \\
\hline Recycling & & & & & & & & & \\
\hline Lack of technical skills & & & & & & & $\underline{v}$ & & \\
\hline Quality compromise & & $\underline{\underline{v}}$ & $\underline{v}$ & & & $\underline{\underline{v}}$ & & & \\
\hline $\begin{array}{l}\text { Disassembly of products is time-consuming and } \\
\text { expensive }\end{array}$ & $\underline{v}$ & $\underline{v}$ & $\underline{v}$ & & & & & & \\
\hline No surety CE will help the environment & & & & & & & & & \\
\hline Quality assurance & & & & & & & & & \\
\hline Design irrespective of CE & & & & & & & & & \\
\hline Hygienic issues & & & & & & & & & \\
\hline
\end{tabular}

When explaining the CE barriers, the first barrier that is mentioned by the respondents is the high start-up cost. This fact is also supported by the literature (Preston, 2012) Liu \& Bai (2014). Every business needs to consider the cost of transition towards any new model.

The next barrier which two respondents have mentioned is the quality issue of recycled materials, as identified by Torstensson (2016). Another barrier identified is that recycling requires a technology-intensive process that needs such high-level testing protocols to ensure that the recycled materials are according to the specification of the customer, that it is difficult to attain. This is supported by Holmes, 2018.

One respondent believes that coordination problems between companies can be a barrier, but it depends mainly on the company and the way they think about the environment and the scarce world resources. In the literature, this phenomenon is considered as a barrier too (Preston, 2012). This also requires international coordination among companies because the transition from linear to $\mathrm{CE}$ requires a change across borders (SMO Promovendi, 2017/2018).

In EOL (eEnd of life) management, the disassembly of products is considered to be an important element. It is considered that almost every product has some amount of disassembly i.e. irreversible joints, maintenance and up-gradation and degradation during use. It is not actually the reverse process of assembly. If the instructions of disassembling are available with other relevant information such as design and life cycle information, this will ultimately help in product disassembly automation and decrease disposal of components (Parlikad et al., 2003). All the respondents said that the disassembly of products is not easy and is expensive and time-consuming because of the complexity of products and this fact is also supported by the literature (Torstensson, 2016). The complexity comes due to different aspects. The number of materials has increased, and many small materials are used with significant importance as well as the multiple components of a different nature. These all come together to affect the transition towards a CE. If the resources contained in these 
materials and components are taken back through repair, upgrade or remanufacture this can be of benefit the world over (Peiró et al., 2017)

Another barrier which the companies have mentioned is that the technology sector pays less attention to the end-phase of a product (Eijk, 2015). One of the problems is the production of cheaper goods, shorter-life expectancy and low cost and unsustainable products in today's corporate culture. The culture of companies is, when they make a product, they don't feel the need to consider how the product will end its life. Once the manufacturers produce the product and send it off for sale, they are not usually responsible for the end-phase of the products' life. Furthermore, there is a lack of information available when recycling or reusing any product in the end phase of life. Product information is necessary to identify and know about the product parts for appropriate disposal. This has encouraged governments and organizations to make strategies to pressurise companies and the corporate world to be more responsible while producing and to have strict environmental considerations \& policies (Hesselbach et al., 2001).

From the interviews, it is evident that manufacturers investigated mainly focus on the lower impact CE strategies and the waste-chain (Figure 1), and less on the elevated strategies with a deeper impact on company operations leading to regenerative approach from the design on new products through the life-cycle management of products and in their manufacturing business.

\section{Discussion}

This section provides the discussion about barriers to the circular economy of ed (Figure 1)The manufacturing companies investigated all are aware of the growing importance of the environmental aspects mentioning efforts to increase reuse, lower $\mathrm{CO}_{2}$ emissions and reduce waste. Authors investigation shows that the transition from traditional environmental considerations towards circular models face several barriers.

${ }_{2}$ with respect to technical products and the barriers, in general, relative to the supply chain. The respondent from Business no.2 says that quality could be an issue in the recycled products. He also mentions that recycling is more expensive than the virgin materials but it depends on the price of the material itself.

Further, if you see it in an environmental perspective it would not be because this is the whole idea of recycling, but if you have a sustainable mind you would probably prefer recycled material over virgin.

Companies give less attention to end phase of the product because there are new products available and they just replace them with the new one. Their thinking about recycling is normal but as it should be. The transition towards a circular economy is expensive and timeconsuming and there are possible complexities in the supply chain as well. He thinks that moving towards a circular supply chain needs a lot of investment.

Regarding the hygienic issues in the recycled materials, he thinks that it depends on the country system i.e. how the products are being handled and recycled so in his perspective economy matters a lot. Coordination among companies in the transition towards CE varies from company to company. Some companies have more focus on environmentally friendly ways of doing business and some have not.

Depending on the size of the company. Global corporate strategies implemented at the large multi-national manufacturers are communicated to subsidiaries. For example, company 1 
promote a commitment to reduce the environmental impact in their business communications. An example is thean annual report; "This commitment is embedded within our governance framework, including our operating system and production system, and therefore is not a standalone environmental policy." The smallest manufacturing company, company 10, do not have a company strategy on sustainability or CE. This indicates that the company size matters for how fast companies move toward $\mathrm{CE}$, but for different reasons for large and small manufacturers. Large manufacturing companies have the knowledge to make a strategy for moving towards CE, but are slow move as it takes time to propagate the strategy to its subsidiaries. Smaller manufacturers lack a unified documented corporate strategy for moving towards CE, but they are able to move faster. An example is company 6 who has developed the "power by the hour" service model but the market is not ready for it yet.

Attributed to the Quality Compromise barrier which concerns the reluctance of putting weight on environmental issues since they fear it will compromise other qualities like performance and the quality of the end-product. As the barriers are based on multi-faced and multi-dimensional factors they are a symptom pointing to an area needs to be addressed, rather than a narrow topic. Clearly, quality compromises and quality assurance barriers are related. To highlight the $\mathrm{CE}$ aspects, we have categorized the responses into barrier-classes based on the characteristics of the CE-mode described in $M+3 R$ model in Figure 1. I.e. according to the level of $\mathrm{CE}$ impact by maintenance, reuse, remanufacturing and recycling plus waste.

Company 6 "Lower quality of recycled materials compared with new":

Attributed to the Quality Compromise barrier which concerns the reluctance of putting weight on environmental issues since they fear it will compromise other qualities like performance and the quality of the end product.

As the barriers are based on multi-faced and multi-dimensional factors they are a symptom pointing to an area needs to be addressed, rather than a narrow topic. Clearly, quality eompromises and quality assurance barriers are related. To highlight the $\mathrm{CE}$ aspects, we have categorized the responses into barrier-classes based on the characteristics of the CEmode described in $M+3 R$ model in Figure 1. I.e. according to the level of CE impact by maintenance, reuse, remanufacturing and recycling plus waste.

\section{Analysis}

This chapter focuses on the data collected in the semi-structured interviews of the ten companies. Based on our analysis, we have identified barriers for moving towards a circular economy $\mathrm{CE}$. We provide recommendations to the companies in manufacturing industries that are in need of any new strategies for handling the transition to a regenerative model adhering circularity of the CE to develop new opportunities to go green, more sustainable, introduce new concepts and systems that minimise waste and comply with all international tawsmodel.

\section{Barriers identified to the circular economyCE in manufacturing industries: A Case Study}

Norwegian The manufacturing companies investigated all are aware of the growing importance of the environmental aspects mentioning efforts to increase reuse, lower $\mathrm{CO}_{2}$ emissions and reduce waste. Our investigation shows that the transition from traditional environmental considerations towards circular models face several barriers. 


\section{Company 1}

know the concept of "circular economy" and have a focus on environmental sustainability. Even if the respondents involved in the research don't use the words "Circular Economy", all their efforts towards environmental protection have a base in this concept. Large Norwegian manufacturing companies give special attention to regeneration of resources, and they have special programmes to implement such concepts as illustrated by the "Revert project", the "sunshine program" ete.

Company B (?)2 overtly recognises its goal towards a sustainable environment and the necessity of charging their customers a small recycling fee that is transferred to the recycling funds to handle recycling. Company $\mathrm{B} 2 \mathrm{~h}$ has membership in an association of recycling companies that make sure electronic product waste is handled carefully and that products are reused instead of new raw materials. By doing this energy consumption is saved, and environmentally friendly products are produced by reducing the global waste. The company is also certified with ISO 14001:2004. This enables the company to comply with the rules and regulations of the environmental management system thereby reducing the negative effects on the environment. There are a lot of different barriers mentioned in the literature review chapter. Some are general barriers, and some are related to the supply chain. There are different barriers identified by the companies whom we have interviewed. Most of the barriers focus on the supply chain in general and product related barriers in particular. Figure $Z$ shows the barriers identified by the companies. In addition to this, Table 2 presents the barriers that are identified by companies and in literature providing a comparison. 
Quality compromise (3) expensive (3)

Disassembly of products is time consuming and

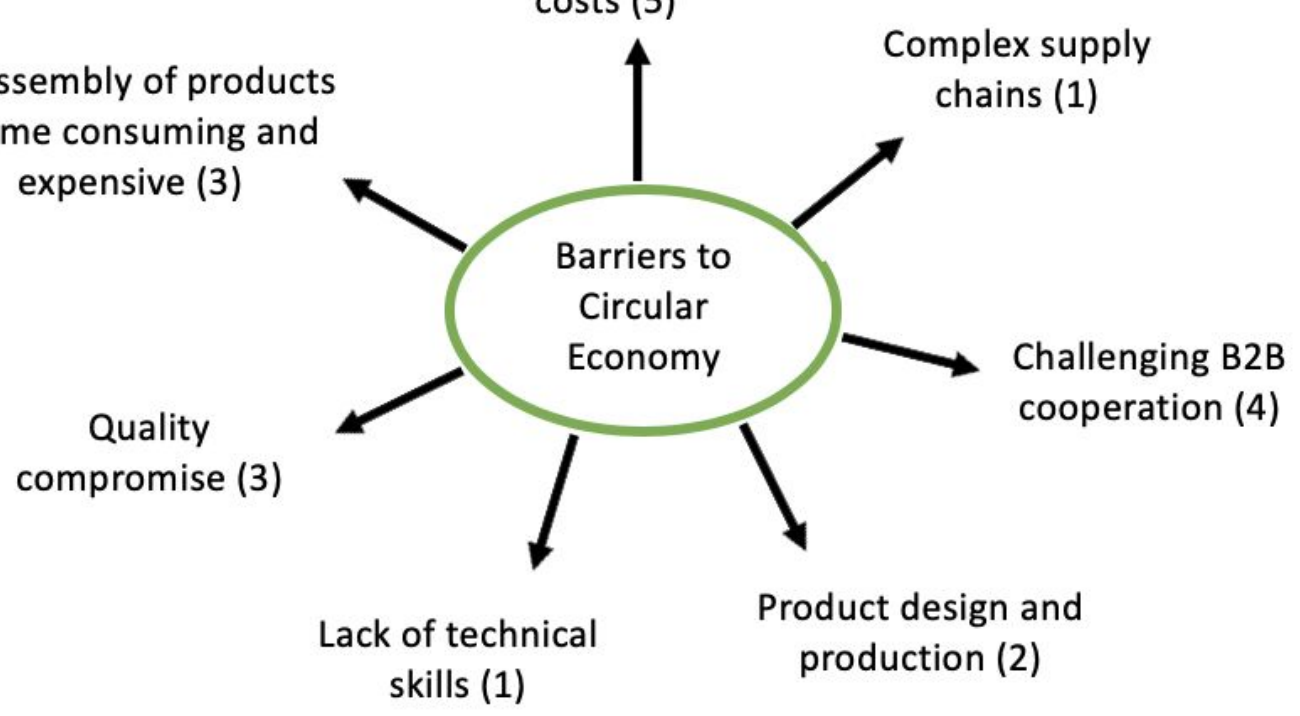

Lack of technical skills (1)

\section{High start-up} costs (5)

Figure 2 Barriers identified by companies (the number of companies identifying each barrier in parentheses)

Table 2: Barriers in literature and by companies

\begin{tabular}{|l|l|l|l|l|l|l|l|l|l|l|l|}
\hline Barriers identified in the literature & \multicolumn{7}{|l|}{ Barriers } \\
manufacturers & by \\
\hline & $\mathbf{4}$ & $\mathbf{2}$ & $\mathbf{3}$ & $\mathbf{4}$ & $\mathbf{5}$ & $\mathbf{6}$ & $\mathbf{7}$ & $\mathbf{8}$ & $\mathbf{9}$ & $\mathbf{1 0}$ \\
\hline Resource-intensive development models & & & & & & & & & & \\
\hline High start up costs & $\forall$ & & $\forall$ & $\forall$ & $\forall$ & & & & & $\forall$ \\
\hline Complex supply chains & & & $\forall$ & & $\forall$ & & & & & \\
\hline Challenging B2B cooperation & & & & & & & & & & & \\
\hline Innovation diffusion challenge & & & & & & & & & & \\
\hline Structurat & & & & & & & & & & \\
\hline Contextuat & & & & & & & & & & \\
\hline Eulturat & & & & & & & & & & \\
\hline Restricted supply chain & & & & & & & & & & \\
\hline Lack of industrial symbiosis & & & & & & \\
\hline
\end{tabular}


When explaining the circular economy $\underline{C E}$ barriers, the first barrier that is mentioned by the respondents is the high start up cost. This fact is also supported by the literature (Preston, 2012) Liu \& Bai (2014). Every business needs to consider the cost of transition towards any new model.

The next barrier which two respondents have mentioned is the quality issue of recycled materials, as identified by Torstenssen, 2016. Another barrier identified is that recyeling requires a technology intensive process that needs such high-level testing protocols to ensure that the recycled materials are according to the specification of the customer, that it is difficult to attain. This is supported by Holmes, 2018.

One respondent believes that coordination problems between companies can be a barrier, but it depends mainly on the company and the way they think about the environment and the scarce world resources. In the literature, this phenomenon is considered as a barrier too (Preston, 2012). This also requires international coordination among companies because the transition from linear to circular economy $\underline{\mathrm{CE}}$ requires a change across borders (SMO Promovendi, 2017/2018).

In EOL (End of life) management, the disassembly of products is considered to be an important element. It is considered that almost every product has some amount of disassembly i.e. irreversible joints, maintenance and upgradation and degradation during use. It is not actually the reverse process of assembly. If the instructions of disassembling are available with other relevant information such as design and life cycle information, this will ultimately help in product disassembly automation and decrease disposal of components (Parlikad et al., 2003). All the respondents said that the disassembly of products is not easy and is expensive and time-consuming because of the complexity of products and this fact is also supported by the literature (Torstensson, 2016). The complexity comes due to different aspects. The number of materials has increased, and many small materials are used with significant importance as well as the multiple components of a different nature. These all come together to affect the transition towards a circular economyCE. If the resources contained in these materials and components are taken back through repair, upgrade or remanufacture this can be of benefit the worldover (Peiró et al., 2017)

Another barrier which the companies have mentioned is that the technology sector pays less attention to the end phase of a product (Eijk, 2015). One of the problems is the production of cheaper goods, shorter life expectancy and low cost and unsustainable products in today's corporate culture. The culture of companies is, when they make a product, they don't feel the need to consider how the product will end its life. Once the manufacturers produce the product and send it off for sale, they are not usually responsible for the end phase of the products' life. Furthermore, there is a lack of information available when recycling or 
reusing any product in the end phase of life. Product information is necessary to identify and know about the product parts for appropriate disposal. This has encouraged governments and organizations to make strategies to pressurise companies and the corporate world to be more responsible while producing and to have strict environmental considerations \& policies (Hesselbach et al., 2001).

From the interviews, it is evident that manufacturers investigated mainly focus on the lower impact CE strategies and the waste-chain (Figure 1), and less on the elevated strategies with a deeper impact on company operations leading to regenerative approach from the design on new products through the life-cycle management of products and in their manufacturing business.

\section{Conclusion}

In this research, authors have explored how the transition towards a eireular econemy $\underline{\mathrm{CE}}$ takes place in manufacturing industries by studying ten companies. For the research question: what are the barriers to the circular economy in the manufacturing industries supply chain? The authors have found that the major barriers for implementation of CE are: were a quality issue in recycled materials; supply chain complexities; coordination problems between companies; design and production of the product; disassembly of products and high start-up/ investment costs.

In the second part of our paper, we explored whether product information management systems can be used to support companies. The barriers we identified confirm what we have found in the literature on barriers. This shows that the companies are well aware of the challenges of moving towards the eireular economy $\mathrm{CE}$. The research further show that the companies currently have a traditional $\mathrm{CE}$ focus attending to policies placing their efforts as low CE effect or very low CE effect actions. In practice, this means they focus on recycling and reducing waste. They have little or no focus on the ideal no-waste scenario, and to a very little extent on high CE-effect. Activities related to servicification can be seen as having high CE effects, as servicification is an important part of the no-waste ideal. However, the servicification attempts seems to come more from a need to address market trends, than as a strategic move towards high CE-effect activities. This research classified the barriers to $\mathrm{CE}$ transition according to the companies' point of view with the barriers derived from the literatures. This classification would be beneficial for the concerned companies, for two reasons. The first one is that it would provide an understanding of the different company's views about the barriers. The second reason is that this enable them to focus on overcoming the barriers that are found to be important to operations with high CE-effect.Our understanding of barriers could help companies in their efforts to move to a Reuse, Remanufacture and Recycle operational approach.

\section{Limitations}

The eireular economy $\mathrm{CE}$ concept is emerging, and manufacturers know this concept but the actual shift towards a circular model is slow in its progression. Companies in this research have promoted their eireular economy $\mathrm{CE}$ commitments and barriers in implementation they experience, in reality, have not adopted the CE concept in full. The data comes from participants in a single country, Norway, although the manufacturers are multinational companies adhering to enterprise policies.

Future research opportunities include: 
- Consideration of the impact of all the standards of GS1 i.e. identification, capture and share.

Comparison of the GS1 standards with other Global standards provider companies i.e. BRC global standards.

- The potential to use other technologies other than GS1 standards i.e. RFID, and other track and trace systems to address the barriers preventing true CE adoption by manufacturing companies.

- Proposed framework through which the circular model can be implemented in the manufacturing sector.

- A cost savings and future profits analysis on manufacturing companies who implement a circular business model in response to CSR focused on the environment. 


\section{References}

Berchicci, L., \& Bodewes, W. (2005). Bridging environmental issues with new product development. Business Strategy and the Environment, 14(5), 272-285.

Bocken, N. M., de Pauw, I., Bakker, C., \& van der Grinten, B. (2016). Product design and business model strategies for a circular economy. Journal of Industrial and Production Engineering, 33(5), 308-320.

Bradford, S. \& Cullin, F., 2012. Research and research methods for youth practitioners. London: Routledge.

Braungart, M., McDonough, W., \& Bollinger, A. (2007). Cradle-to-cradle design: creating healthy emissions-a strategy for eco-effective product and system design. Journal of cleaner production, 15(13-14), 1337-1348.

Damen, M.A., 2012. A Resource Passport for a Circular Economy: An assessment of the possible content and format of a resources passport in order to successfully contribute to the achievement of the circular economy. Master Thesis. Utrecht University, Faculty of Geosciences.

Eijk, F.V., 2015. Barriers \& Drivers towards a Circular Economy. Literature Review A140315-R-Final. Naarden, The Netherlands: Acceleration.

Ellen MacArthur Foundation. (2013). Towards the Circular Economy.

Ellen MacArthur Foundation. (2014). Towards the Circular Economy: Accelerating the Scale-up Across Global Supply Chains.

Ellen MacArthur Foundation. (2015). Towards a Circular Economy: Business Rationale for an Accelerated Transition.

Erkman, S., 1997. Industrial ecology: an historical view. Elsevier Science, 5, pp.1-10.

[EU 2017] Investing in a smart, innovative and sustainable Industry A renewed EU Industrial Policy Strategy (2017). Brussels, 13.9.2017 COM (2017) 479 final. https://eurlex.europa.eu/resource.html?uri=cellar:c8b9aac5-9861-11e7-b92d-

01aa75ed71a1.0001.02/DOC_1\&format=PDF

[EU-GPP] Buying green! A handbook on green public procurement 3rd Edition (2016)http://ec.europa.eu/environment/gpp/pdf/Buying-Green-Handbook-3rd-Edition.pdf

Genovese, A., Acquaye, A.A., Figueroa, A. \& Koh, S.C.L., 2017. Sustainable Supply Chain Management and the transition towards a Circular Economy: Evidence and some Applications. Omega, 66(white Rose Research), pp.344-57.

GS1, 2017. Annual Report 2016-2017. GS1. 
GS1, 2018. GS1 General Specifications: The foundational GS1 standard that defines how identification keys, data attributes and barcodes must be used in business applications. specification. Brussels: GS1.

Herman, E. (2016). The importance of the manufacturing sector in the Romanian economy. Procedia Technology, 22, 976-983.

Hesselbach, J., Herrmann, C., Ohlendorf, M. \& Graf, R., 2001. Approach of Substance Flow Oriented Closed Loop Supply Chain Management in the Electrical and Electronic Equipment Industry.

Holmes, K., 2018. Recycling: The Importance of Quality-Assurance Testing for Recycled Materials. [Online] Gardner Business Media, Inc Available at: https:/www.ptonline.com/columns/recycling-the-importance-of-quality-assurance-testingfor-recycled-materials- [Accessed 2 October 2018].

Hopkinson, P., Zils, M., Hawkins, P., \& Roper, S. (2018). Managing a complex global circular economy business model: opportunities and challenges. California Management Review, 60(3), 71-94.

Irani, Z., \& Sharif, A. M. (2018). Food security across the enterprise: a puzzle, problem or mess for a circular economy? Journal of Enterprise Information Management, 31(1), 2-9.

Kärkkäinen, M., \& Holmström, J. (2002). Wireless product identification: enabler for handling efficiency, customisation and information sharing. Supply chain management: an International Journal, 7(4), 242-252.

Leblanc, R., 2018. An Introduction to Metal Recycling. [Online] Available at: https://www.thebalancesmb.com/an-introduction-to-metal-recycling-4057469.

Liakos, N., Kumar, V., Pongsakornrungsilp, S., Garza-Reyes, J., Gupta, B., \& Pongsakornrungsilp, P. (2019). Understanding circular economy awareness and practices in manufacturing firms. Journal of Enterprise Information Management, 32(4), 563-584.

Lieder, M., \& Rashid, A. (2016). Towards circular economy implementation: a comprehensive review in context of manufacturing industry. Journal of cleaner production, 115, 36-51.

Liu, Y., \& Bai, Y. (2014). An exploration of firms' awareness and behavior of developing circular economy: An empirical research in China. Resources, Conservation and Recycling, 87, 145-152.

Lucas, P., Kok, M., Nilsson, M., \& Alkemade, R. (2014). Integrating biodiversity and ecosystem services in the post-2015 development agenda: goal structure, target areas and means of implementation. Sustainability, 6(1), 193-216.

Marquez, C., 2010. Dynamic Modelling for Supply Chain Management. Dealing with Frontend, Back-end and Integration issues, p.297.

Masi, D., Day, S. \& Godsell, J., 2017. Supply Chain Configurations in the Circular Economy: A Systematic Literature Review. Sustainability, 9, p.22. 
Majta, M., 2012. Managing the Risks of a Globalized Supply Chain. [Online] Available at: https://www.forbes.com/sites/ciocentral/2012/10/04/managing-the-risks-of-a-globalizedsupply-chain/\#59720e9e39d8 [Accessed 8 August 2018].

Naz, F. and Rahim, K. K., 2018. Shift towards Circular Economy in technical industries with the help of the product information system \& standardization. Master's degree thesis, Molde University College

Nikbakhsh, E., 2009. Green Supply Chain Management. Supply Chain and Logistics in National, International and Governmental Environment, pp.195-220.

[Norwegian-Forskrift-2017] Forskrift om offentlige anskaffelser (anskaffelsesforskriften), (2017) Kapittel 7. Fellesbestemmelser, § 7-9. Minimering av miljøbelastning https://lovdata.no/dokument/SF/forskrift/2016-08-12-974

Preston, F., 2012. A Global Redesign? Shaping the circular economy. Briefing paper. London: Soapbox Chatham House.

Ritzéna, S. \& Sandström, G.Ö., 2017. Barriers to the Circular Economy - Integration of Perspectives and Domains. Procedia CIRP, 64 (Elsevier), pp.7-12.

Rizos, V. et al., 2015. The Circular Economy: Barriers and Opportunities for SMEs. CEPS Working document 412, September.

Sheffi, Y. (2018). Balancing Green: When to Embrace Sustainability in a Business (and When Not To). MIT Press.

Testa, F., Annunziata, E., Iraldo, F., \& Frey, M. (2016). Drawbacks and opportunities of green public procurement: an effective tool for sustainable production. Journal of Cleaner Production, 112, 1893-1900.

Thomas, D.R., 2006. A General Inductive Approach for Analyzing Qualitative Evaluation Data. American Journal of Evaluation, 27 (2006 American Evaluation Association), pp.23746.

Torstensson, L.A., 2016. Internal barriers for moving towards circularity-- An industrial perspective. Master Thesis MMK 2016:151. Stockholm Sweden: MCE 336 KTH Industrial Engineering and management.

Yin, R. K. 1994. Case study research: design and methods: 2 ed: Sage Publications.

Zhu, Q., Geng, Y., \& Lai, K. H. (2010). Circular economy practices among Chinese manufacturers varying in environmental-oriented supply chain cooperation and the performance implications. Journal of Environmental Management, 91(6), 1324-1331.

Zhijun, F., \& Nailing, Y. (2007). Putting a circular economy into practice in China. Sustainability Science, 2(1), 95-101 


\section{Guest Editor's comments}

The paper still needs significant improvements before any decision can be made on the publication of the research:

Q. The structured abstract is lengthy, please keep the narrative to the point for each section.

Ans. Thank you for this comment, we have revised our abstract and made it more precise and to the point.

Q. Sources used to identify barriers are limited to only a handful of studies; perhaps this can be expanded to show wider reading

Ans. Many thanks for pointing out this issue. We have added some more literature, Braungart et al and Liakos et al (latest paper published in JEIM).

Q. Reduce the quotations as some are equivalent to large paragraphs. The authors should also analyse the quotes in more detail and offer a critical synthesis of the key emergent discussions

Ans. We have noted this comment and reduced the size of quotations and analysed them in a better manner.

Q. The large, bulky quotes does not add value to the work, rather it seems lazy. Please use only part of the quotes that are relevant and has a real value to the arguments that you are trying to make.

Ans. We have removed the more general aspects mentioned by respondents in the quotes, keeping the parts relevant to the issues discussed. For each company, we have added a discussion of the quotes relating them to the theoretical CE-model in Fig. 1.

Q. Provide a participants profile table including the company details to make it easier to identify the participants of the research (can't see it even though they said they've included it)

Ans. Thank you for this interesting comment. We have updated the table with details about each company, including company name, turnover, and the person(s) interviewed (except for one that is anonymous). We provide the table at the end of this document (Table 3: Overview of companies investigated) for editors and reviewers, approval by the companies are needed in case this information shall be published.

Q. What was the sampling strategy and how were the companies approached? Furthermore, how were the participants identified at each organisation.

Ans. We have added a description of the selection process of manufacturing companies and the persons interviewed. 
Q. Discussion is weak and lacks reference to existing studies. How do the findings from this research tie in with existing studies. Although studies are cited in the analysis, it should include more studies which are also more timely in order to offer a wider, yet critical perspective.

Ans. Thank you for this comment. The updated discussion related to the quotes by each company linking it with the CE-model of Figure 1 might be seen as partly addressing this issue.

Q. The analysis section should come before the discussion.

Ans. Thank you for this suggestion, we have moved analysis before the discussion.

Q. I am still not convinced of how they analysed the interviews, there is not discussion relating to the codes and how these were generated or how they link to broader themes. This needs to be revisited and evidenced by including the coding process.

Ans. We have expanded the "Data Collection" section to clarify this. Also explicitly stating that since we investigate a social phenomenon, our qualitative analysis of the interviews is based on our interpretive classification. It was not codified or statistically analysed. This approach satisfies our goal by this research in classifying the barriers to CE transition according to the companies' point of view with the barriers derived from the literature.

Q. Offer practical and theoretical contributions as separate sections within the discussions section.

Ans. Thank you for this comment. We have added a separate section within the discussion on theoretical and practical contribution. 


\section{Reviewer 1}

\section{Recommendation: Minor Revision}

\section{Comments:}

The paper has been significantly improved from earlier version. However, a few issues still need to be taken care of. The following are comments and issues to take note of.

1. Yes, the paper makes a valuable contribution to our understanding of issues regarding circularity.

2. Yes, the paper demonstrates a very good understanding of the relevant literature.

3. Yes, the paper argument is based on the use of relevant literature and theory. The appropriate method (qualitative research - interviews) was used in the study.

4. Yes, the results are clearly presented. However, the discussion section needs to be improved. Ideally, the separate Discussion and Analysis sections could be combined together and given the section heading 'Analysis and Discussion'. In addition, some if not most of the texts used with the interviews descriptions could be moved to the new section headed 'Analysis and Discussion. The interview narratives should be used in the discussion.

\section{Ans. Many thanks for this comment. As guest editor also pointed out these issues and suggested us to move analysis before the discussion section and keep them separate.}

5. The practical implications (and theoretical implications) of the study could be improved. A section on Implications will be in the right order. Hence the section conclusion should be renamed Implications and the implications of the study should be well articulated under this section.

\section{Ans. Thank you for this comment. The guest editor also commented on the implication part. As suggested by the guest editor, we have moved the implication in the discussion.}

6. Quality of communication OK. However, final proofing will still be required.

\section{Ans. Thank you, we have done the final proofreading now.}

Additional Questions:

$<b>1$. Originality: $</ b>$ Does the paper contain new and significant information adequate to justify publication?: Yes, the paper makes a valuable contribution to our understanding of issues regarding circularity.

Thank you

$<b>2$. Relationship to Literature: $</ b>$ Does the paper demonstrate an adequate understanding of the relevant literature in the field and cite an appropriate range of literature sources? Is any significant work ignored?: Yes, the paper demonstrates a very good understanding of the relevant literature. 
$<b>3$. Methodology: </b>ls the paper's argument built on an appropriate base of theory, concepts, or other ideas? Has the research or equivalent intellectual work on which the paper is based been well designed? Are the methods employed appropriate?: Yes, the paper argument is based on the use of relevant literature and theory. The appropriate method (qualitative research - interviews) was used in the study.

Thank you

$<b>4$. Results: $</ b>$ Are results presented clearly and analysed appropriately? Do the conclusions adequately tie together the other elements of the paper?: Yes, the results are clearly presented. However, the discussion section needs to be improved. Ideally, the separate Discussion and Analysis sections could be combined together and given the section heading 'Analysis and Discussion'. In addition, some if not most of the texts used with the interviews descriptions could be moved to the new section headed 'Analysis and Discussion. The interview narratives should be used in the discussion.

Ans. Many thanks for this comment. As guest editor also pointed out these issues and suggested us to move analysis before the discussion section and keep them separate.

$<b>5$. Practicality and/or Research implications: $</ b>$ Does the paper identify clearly any implications for practice and/or further research? Are these implications consistent with the findings and conclusions of the paper?: The practical implications (and theoretical implications) of the study could be improved. A section on Implications will be in the right order. Hence the section conclusion should be renamed Implications and the implications of the study should be well articulated.

Ans. Thank you for this comment. The guest editor also commented on the implication part. As suggested by the guest editor, we have moved the implication in the discussion.

$<b>6$. Quality of Communication: $</ b>$ Does the paper clearly express its case, measured against the technical language of the field and the expected knowledge of the journal's readership? Has attention been paid to the clarity of expression and readability, such as sentence structure, jargon use, acronyms, etc.: Quality of communication OK. However, final proofing will still be required. 


\section{Reviewer 2}

Recommendation: Accept

Comments:

All the comments are addressed individually and satisfactorily to improve the paper as required. Good job.

Best wishes.

Thank you

Additional Questions:

$<b>1$. Originality: $</ b>$ Does the paper contain new and significant information adequate to justify publication?: Yes, the authors have addressed the concerns raised to justify for the publication.

Thank you

$<b>2$. Relationship to Literature: $</ b>$ Does the paper demonstrate an adequate understanding of the relevant literature in the field and cite an appropriate range of literature sources? Is any significant work ignored?: Yes, the paper demonstrates adequate understinding of the relevant literature and the authors have cited appropriate range of good literature sources. The subsection suggested earlier has been added satisfactorily.

Thank you

$<b>3$. Methodology: </b>ls the paper's argument built on an appropriate base of theory, concepts, or other ideas? Has the research or equivalent intellectual work on which the paper is based been well designed? Are the methods employed appropriate?: The methodology has been improvised to address previous comments. This looks well designed and methods employed look appropriate.

Thank you

$<b>4$. Results: $</ b>$ Are results presented clearly and analysed appropriately? Do the conclusions adequately tie together the other elements of the paper?: This section has been improvised satisfactorily as per the previous comments and looks good now.

Thank you

$<b>5$. Practicality and/or Research implications: $</ b>$ Does the paper identify clearly any implications for practice and/or further research? Are these implications consistent with the findings and conclusions of the paper?: Yes, the paper clearly identifies the limitations and these are consistent with the findings and conclusions. 
Thank you

$<b>6$. Quality of Communication: $</ b>$ Does the paper clearly express its case, measured against the technical language of the field and the expected knowledge of the journal's readership? Has attention been paid to the clarity of expression and readability, such as sentence structure, jargon use, acronyms, etc.: Overall, the paper is written well and the authors have addressed previous comments through proof reading and mitigating inconsistency in language.

Thank you

Table 3: Overview of companies investigated 


\begin{tabular}{|c|c|c|c|}
\hline & Company & Company information & $\begin{array}{l}\text { Person(s) } \\
\text { interviewed }\end{array}$ \\
\hline 1 & $\begin{array}{l}\text { Roll Royce } \\
\text { Commercial } \\
\text { Marine }\end{array}$ & $\begin{array}{l}\text { Manufacturer of marine propulsion } \\
\text { systems. Annual turnover of } 919 \text { mill euro. } \\
\text { Rolls-Royce plc.'s commercial marine } \\
\text { products, systems and aftermarket services } \\
\text { business ("Rolls-Royce Commercial } \\
\text { Marine"). Rolls-Royce Commercial Marine } \\
\text { is the commercial marine business within } \\
\text { the Rolls-Royce group that supplies } \\
\text { components, systems and digital elements } \\
\text { primarily for civil marine vessels. } \\
\text { https://www.rolls- } \\
\text { royce.com/ /media/Files/R/Rolls- } \\
\text { Royce/documents/annual-report/2017/rr- } \\
\text { plc-annual-report-2017.pdf } \\
\text { Revert program: https://www.rolls- } \\
\text { royce.com/media/our- } \\
\text { stories/discover/2017/revert.aspx }\end{array}$ & Anonymous \\
\hline 2 & Glamox & $\begin{array}{l}\text { Manufacturer of professional lighting } \\
\text { solutions. Annual turnover } 236 \text { million } \\
\text { euro. } \\
\text { https://glamox.com/upload/2018/05/25/a } \\
\text { rsrapport } 2017 \text { en.pdf } \\
\text { Glamox and the Environment: } \\
\text { https://glamox.com/corporate/glamox- } \\
\text { and-the-environment }\end{array}$ & $\begin{array}{l}\text { Terje } \\
\text { Andersen, } \\
\text { Group IT- } \\
\text { manager }\end{array}$ \\
\hline 3 & $\begin{array}{l}\text { GS1 } \\
\text { Norway }\end{array}$ & $\begin{array}{l}\text { Standardization company. Global } \\
\text { Standards } 1 \text { (GS1) is a not-for-profit } \\
\text { company that develops global standards } \\
\text { for business to business communication. } \\
\text { GS1 was established in February 2005, by } \\
\text { the merger of EAN International (European } \\
\text { Article Numbering) and UCC (Uniform Code } \\
\text { Council). The best known GS1 standards are } \\
\text { the barcode and RFID standards. GS1 } \\
\text { Norway has fifteen employees. This } \\
\text { interview was conducted in the } \\
\text { Department of Delivery Standards where } \\
\text { we interviewed Terje Menkerud, a senior } \\
\text { advisor at GS1. GS1 Norway has more than } \\
6300 \text { registered companies in Norway. }\end{array}$ & $\begin{array}{l}\text { Terje } \\
\text { Myklebust, } \\
\text { Senior } \\
\text { Advisor }\end{array}$ \\
\hline 4 & Hydro & $\begin{array}{l}\text { Manufacturer of aluminium. } \\
\text { Yearly turnover } 3,9 \text { billion euro. } \\
\text { https://www.hydro.com/en- } \\
\text { NO/media/when-experts-unite/ }\end{array}$ & $\begin{array}{l}\text { Erling Johan } \\
\text { Wollen, SAP } \\
\text { Consultant, } \\
\text { Logistics. } \\
\end{array}$ \\
\hline
\end{tabular}




\begin{tabular}{|c|c|c|c|}
\hline & & & $\begin{array}{l}\text { Bjørn } \\
\text { Martin } \\
\text { Kvande, } \\
\text { Senior } \\
\text { Accounting } \\
\text { Consultant } \\
\end{array}$ \\
\hline 5 & Ekornes & $\begin{array}{l}\text { Manufacturer of furniture. Yearly turnover } \\
220 \text { million euro. } \\
\text { http://www.ekornes-contract.com/nb- } \\
\text { no/home/norway/om-ekornes/miljo-og- } \\
\text { samfunnsansvar }\end{array}$ & \begin{tabular}{|l|} 
Andrea \\
Isaksen \\
Schmidt, \\
eCommerce \\
Coordinator \\
Solveig \\
Gaundal, \\
CSR \\
Manager \\
\end{tabular} \\
\hline 6 & Brunvoll & $\begin{array}{l}\text { Manufacturer of marine propulsion and } \\
\text { thruster systems. Yearly turnover } 100 \\
\text { million euro. } \\
\text { http://epub.ekh.no/b/brunvoll/50353/files } \\
\text { Lassets/common/downloads/Brunvoll\%20 } \\
\text { Annual\%20Report\%202015.pdf }\end{array}$ & $\begin{array}{l}\text { Inger } \\
\text { Helene } \\
\text { Hals, Vice } \\
\text { President. } \\
\text { Thomas } \\
\text { Vekve, } \\
\text { Manager } \\
\text { Product } \\
\text { Developme } \\
\text { nt. }\end{array}$ \\
\hline 7 & Optimar & $\begin{array}{l}\text { Manufacturer of automated fish handling } \\
\text { systems. https://optimar.no/ } \\
\text { Yearly turnover } 115 \text { million euro. } \\
\text { https://www.haniel.de/en/press/aktuelles } \\
\text { /optimar/ }\end{array}$ & $\begin{array}{l}\text { Rolf Gunnar } \\
\text { Johansen, } \\
\text { Engineer, } \\
\text { 3D design }\end{array}$ \\
\hline 8 & $\begin{array}{l}\text { Bostek - } \\
\text { Bertel O. } \\
\text { Steen } \\
\text { Teknikk AS }\end{array}$ & $\begin{array}{l}\text { Manufacturer of marine generator sets for } \\
\text { maritime applications. } \\
\text { Yearly turnover } 22 \text { mill Euro. } \\
\text { http://bostek.no/en/about-us/ }\end{array}$ & $\begin{array}{l}\text { Lars Erik } \\
\text { Holo, } \\
\text { Manager. } \\
\text { Eirik Nesse, } \\
\text { Director } \\
\text { Business } \\
\text { Developme } \\
\text { nt } \\
\end{array}$ \\
\hline 9 & Plasto & $\begin{array}{l}\text { Manufacturer of thermoplastic products } \\
\text { for automotive, furniture, and electronics. } \\
\text { Yearly turnover } 8 \text { million euro. } \\
\text { https://plasto.no/en/history/ }\end{array}$ & \begin{tabular}{|l|} 
Runar \\
Stenerud, \\
Managing \\
director. \\
\end{tabular} \\
\hline $\begin{array}{l}1 \\
0\end{array}$ & CodelT & $\begin{array}{l}\text { Manufacturer of Industrial Automation } \\
\text { systems. Yearly turnover 3,5 million euro. } \\
\text { https://codeit.no/about/ }\end{array}$ & $\begin{array}{l}\text { Bjørnar } \\
\text { Torsnes, } \\
\text { Managing } \\
\text { director }\end{array}$ \\
\hline
\end{tabular}


The interviews in this research project were conducted as part of the Manufacturing Networks 4.0 project funded by the Norwegian Research Council. Work Package 4 led the collection of data involving the following persons: for the interviews: K. Rahim and F. Naz conducted the interviews with company 1, 2 and 3.1 via email, 2 and 3 face to face. B. Jæger conducted the interviews with companies $4,5,7,10$ via phone. E. F. Ullern and J. Halfdanarson conducted the interviews with company 6,8 and 9 face to face. 